\title{
Organisational Design Alternatives within International Operations Networks: A Transaction Cost Perspective
}

\author{
Michel Leseure
}

Please reference this paper as:

Leseure, M. (2010), “Organisational design alternatives within international operations networks: a transaction cost perspective", International Journal of Service and Operations Management, Vol. 7, No.

4, pp. 419-439.

\begin{abstract}
This paper shows, through multiple case studies of Moroccan textile apparel offshore factories, that one organisational design does not fit all within international operations networks. Whereas previous research about managing networks of foreign factories has focused on fully owned production affiliates, a considerable diversity of organisational arrangements is shown to exist. Analysed in the light of transaction cost theory, this diversity suggests that the cost of co-ordination of foreign factories operating in culturally different countries is high, and has possibly been overlooked in international operations management research. As this paper is primarily a piece of exploratory research, its aim is to document the hybrid arrangements, between markets and hierarchies, that are used by multinationals to cope with co-ordination costs in practice. Moreover, the potential of "supply chain outposts" as an organisational innovation used to cope with high co-ordination requirements is highlighted.
\end{abstract}

\section{Keywords}

International operations network, transaction cost theory, co-ordination.

\section{Introduction}

The paper is the result of an unexpected discovery in the course of researching the validity of international operations management theory in the context of the Moroccan textile apparel offshore industry. Initially, the purpose of the research was to test, through multiple case studies, the validity of the seminal typology of international factories proposed by Ferdows (1989). Such a research programme (Ferdows, 1989; Meijboom and Vos, 1997; Vereecke and Van Dierdonck, 2002) is usually 
conducted from the perspective of the investor. For example, Ferdows' multiple case studies are based on the study of the foreign subsidiaries of large US multinationals. Vereecke and Van Dierdonck (2002) use a sample of foreign subsidiaries of eight Western Europe manufacturing companies.

The research design used in this paper was different in that the data collected was about the destination (Morocco) rather than the source of invested funds. This apparently innocuous detail led to the realisation that Moroccan offshore textile factories operating with Global Production Networks (GPN) exhibited a wide diversity of organisational arrangements and modes of co-ordination. These arrangements are not identified, documented and explained in the international operations management literature. The purpose of this paper is, through an exploratory multiple case study research methodology, to describe this diversity in the lens of transaction cost theory, to formulate key propositions, and to discuss their consequences for international operations management research.

As such, this paper inscribes itself in a recent stream of research where cultural factors and country effects are used to revisit extant international business models. Although culture has always been a key variable in international business and international operations management research, recent findings show that past research has overlooked the importance of the magnitude and type of cultural risk at stake when valuing a foreign investment, and that many international business models are not robust over wide ranges of values linked to culture and country effects (Li and Rugman, 2007; Tong et al., 2008a; Tong et al., 2008b). It is due to the nature of this new research stream, i.e. to the fact that complex country, cultural and industry-level variables form complex patterns of uncertainty for managers, that many scholars have used transaction cost theory to guide their investigation (Reuer and Tong, 2005; Ellram et al., 2008; Stringfellow et al., 2008). 


\section{Literature Review}

\subsection{Making the Most of Foreign Factories}

A cornerstone of the international operations management literature is Ferdows' $(1989,1997 a, 1997 b)$ contribution. Ferdows developed the model of strategic roles for foreign factories displayed in figure 1, based on case studies of the foreign activities of large US multinationals. His typology of strategic role is based on (1) the primary reason for establishing a site and (2) the extent and nature of technical activities which take place at the site. Ferdows' observations lead him to the conclusion that multinationals that view their foreign factories as sources of competitive advantage, and which actively manage improvement and integration programmes, are those which end up with strong, highly competitive, internationally distributed manufacturing networks. One of his recommendations is that multinationals should make sure that they "make the most out of their foreign factories". 


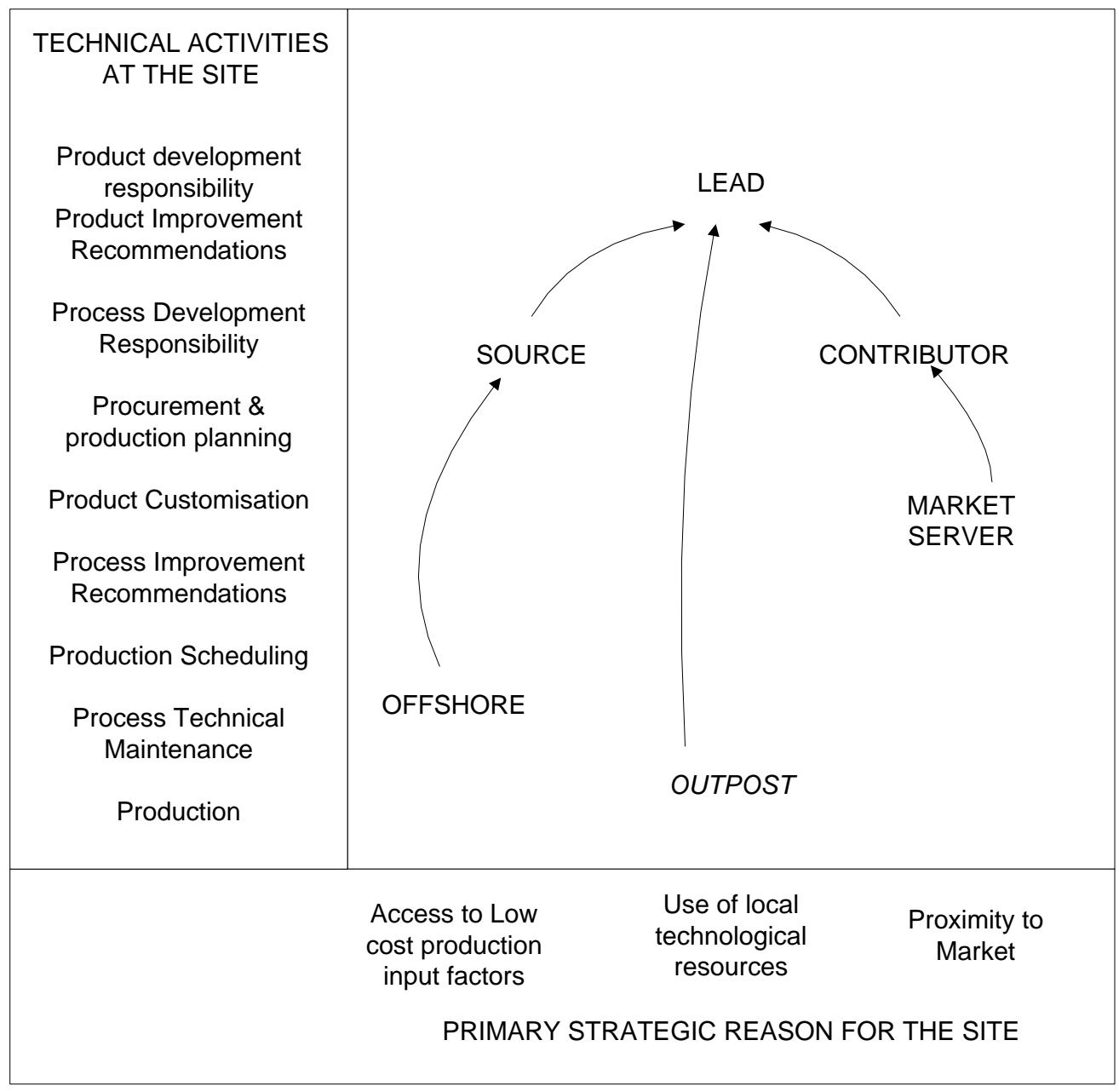

Figure 1. Ferdows' Model of the Strategic Role of International Factories (from Ferdows, 1989).

Prior to Ferdows' model, operations management researchers concentrated on the analysis of coordination requirements and mechanisms: given a manufacturing network topology, how should the different manufacturing, improvement and development activities be co-ordinated world-wide (McGrath and Bequilard, 1989)? Meijboom and Vos (1997) observed that strategic role and coordination decisions are seldom integrated in practice. They use four case studies of Dutch subsidiaries in Thailand to show that strategic role decisions and co-ordination decisions are interdependent. In other words, strategic role and co-ordination mechanisms should in practice form common selfconsistent patterns, or organisational configurations (Meyer et al., 1993). 
Vereecke and Van Dierdonck (2002) tested Ferdows' model through a mixed research design involving structured interviews and the collection of questionnaire data. Their research found strong support for Ferdows' model but highlighted the following points:

- There is little support for the outpost configuration, a fact which is acknowledged by Ferdows' latest publications.

- Their findings indicate that all plants, rather than only a few "centre of excellences", contribute knowledge and examples of excellence.

- There is support for the proposition that foreign factories have moved along one of Ferdows' improvement paths. This finding is moderated by the fact there are divergence between the parents and affiliates' perceptions of the affiliates' strategic role. This point is of critical relevance for this paper, as it suggest that existence of governance and co-ordination issues.

It is important to highlight the relationship between Ferdows' improvements paths and the modern concept of operations networks. The central recommendation of Ferdows is to invest in foreign affiliates, instead of managing them as low-brough, antiquated technical sites. If a company does so, the affiliate becomes a source of knowledge and innovative idea, as well as a possible means through which global risks can be hedged. Khurana and Talbot (1998) provide an empirical proof of the existence of this phenomenon in the global colour picture tube industry. Khurana and Talbot formulated a number of research propositions based on traditional international business entry strategy models and found little support for these propositions. Their conclusion is that traditional models of factory locations cannot predict modern practices, as the true benefits of international operations in modern days are derived from network effects.

\subsection{Network effects}

Network effects are for example the benefits of multinationality. These benefits include economies of scale, economies of scope, learning and real options (Kogut, 1984). Similarly, Buckley and Casson (1998) 
argue that multinationals, due to their widespread operations base, should be able to adapt flexibly to environmental variance, and thus, should exhibit higher performance levels than domestic firms. Kogut and Kulatilaka (1994) illustrate that multinationality can be a source of value added in the face of uncertainty by simulating the ability to switch manufacturing facilities as exchange rate fluctuates. With a real options valuation approach, Kogut and Kulatilaka (1994) are able to assess this value added in financial terms under different scenarios of uncertainty.

The extent to which international operations network are able to exercise this flexibility in practice is a controversial point. For example, Kogut and Kulatilaka (1994) conclude that the ability to take advantage of an international operations network is constrained by the feasibility of managing a supply chain with contracts allowing the exercise of switching options.

The idea that multinational operations leads to increased performance, is on one hand, rejected by Reuer and Leiblin's empirical test (2000). Reuer and Leiblin (2000) posit that due to their non-imitable flexibility, multinational should exhibit lower downside risk than non-international firms. Their empirical study, however, fails to support this hypothesis. On the other hand, there is a wealth of conceptual and case study evidence which stress that there is a current evolution away from vertically-integrated multinational firms toward organisational networks (Julien et al., 1998). Ernst and Kim (2002) describe GPNs as a recent organisational innovation with the purpose of diffusing knowledge globally. Consistently with Ferdows' recommendations (1989), the objective of global production networks is therefore to contribute to local capability formation more effectively. This perspective is also consistent with Shi and Gregory (1998) who show through case studies that international manufacturing networks are an emerging phenomenon used by companies to develop their global competitive capabilities. 


\subsection{Network Effects and Transaction Costs}

Thus, the literature on international operations network has been conceptually strong, but empirical evidence confirming the performance benefits of these networks has been lagging behind theory. It is only recently that some empirical tests have tried to close this gap. Tong and Reuer (2007), when testing the hypothesized link between multinationality and reduced risk level, contrast the options switching potential of international operations network with the actual cost of co-ordinating the exercise of a switching option. Their conclusion is that the relationship between multinationality and risk levels is not linear. Their empirical results, based on a sample of US manufacturing firms, show that exposure to risk first declines as a firm starts to invest internationally, and then increases as international investments are intensified. They also show that increasing risk levels are linked to investments which, culturally speaking, are distant from the multinational's home country. In the context of the value of growth options embedded in international joint ventures, Reuer and Tong (2005) show empirically that under certain circumstances, valuable options exist. Their conclusion, however, are that applications of real options theory to the design of alliance and joint ventures should consider more operational and managerial details than it has in the past in order to explain when valuable options exist. Reuer and Tong (2005) model this detailed context with reference to transaction cost theory.

Thus, the literature on multinational networks had come back full circle to highlighting the issue of coordination, which was once at the forefront of the research agenda (McGrath and Bequillard, 1989). It is noteworthy that Kogut and Kulatilaka (1994) quote Hymer as saying: "A foreign company operates at a disadvantage relative to local firms; it must control the operations over longer distance and it has a handicap in a foreign culture". Their analysis is that this perspective has lost relevance in the context of the study of multinational networks as network effects greatly offset this handicap. This, today, appears to possibly have been a hasty conclusion. For example, Khatawala, Zhang and Shao (2005), in their 
study of how outsourcing practices affect organisational effectiveness, stress the importance of cultural interfaces. Similarly, research about the offshoring of professional services show that cultural and "invisible" costs are paramount considerations (Ellram et al., 2008; Stringfellow et al., 2008). Therefore, the focus of this paper is not on discussing further the performance of international operations networks but instead on presenting the organisational and co-ordination diversity used for managing firms which are part of international operations networks where cultural risks and uncertainty are potentially high.

\section{Research Methodology and Data Collection}

\subsection{Choice of Country}

Although initially motivated by convenience (the author held an academic position in Morocco from 1999 to 2007), the decision to focus on one country and one industry is justified by the fact that it is together that country and industry effects explain organisational arrangements (Tong et al., 2008a).

Morocco has the unlucky characteristic of being one of the only North African countries with no oil reserves. As a result, it has a traditional economy based on agriculture and the mining of its main natural resource, phosphate. Efforts were made in the 1970s and 1980 s to develop a production and service economy, in particular through investment in its offshore textile apparel industry and its tourism sector. The tourism sector, initially successful, collapsed in the late eighties, and government's actions are currently under way to try to revive this sector. Although the textile sector could be described to have been in crisis for the last 10 years, especially in the context of competition with new European Union members and China, there are still a fair number of textile apparel factories in business. Remaining factories are trying to gradually abandon competing on cost for an operations strategy based on the manufacture of small, urgent, difficult to assemble, textile products. This strategy attempts to capitalise on Morocco's geographical proximity to Europe, its free trade agreement with the United 
States, and the know-how accumulated in the past three decades. As the vast majority of Moroccan firms working in the textile apparel industry serve exclusively foreign markets under bonded factories regulations, it has an ideal field of observation of members of global production networks.

\subsection{Research Design}

\subsubsection{Theoretical Background}

The literature review showed that the initial concern about co-ordination and cost of governance expressed by early international operations researchers is a key variable to explain which GPNs provide unique sources of corporate value.

The traditional focus on co-ordination research in operations management (e.g. McGrath and Bequillart, 1987; Meijboom and Vos, 1997) has been to determine which technical activities should be delegated to the foreign factory and which should be retained by the owner of the network. Consequently, this is the sort of data which was collected in order to compare cases with one another. The data was then analysed in the theoretical context of the transaction cost theory of Williamson $(1975,1985)$ in order to enrich the traditional perspective on co-ordination used in international operations management research.

The essence of transaction cost theory it to counter the historical dominance of make or buy accounting models in outsourcing decisions by stressing the importance of adopting a full cost approach, rather than focusing solely on manufacturing costs. Transaction cost theory investigates the cost of managing a specific transaction. It deals with non-production cost, such as: information costs, risk-related costs, cost of contracts, cost of enforcing contracts, cost of drawing specifications, cost of creating and maintaining trust, etc.

According to Williamson (1975), managers select governance modes that will minimise transaction costs, through a decision process summarised in the influence diagram shown in figure 2. 


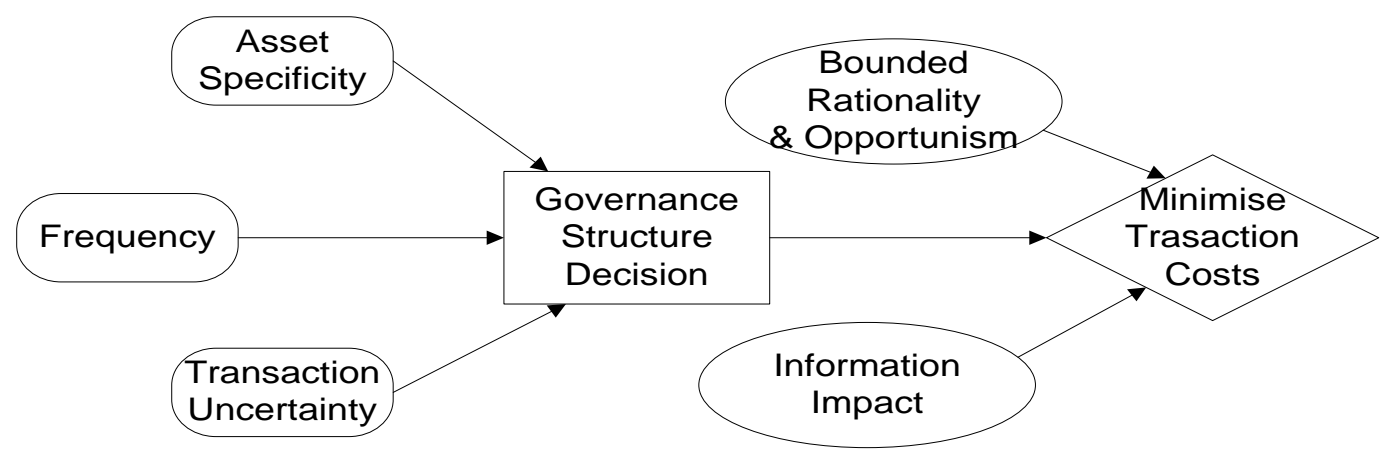

Figure 2. Influence Diagram for Transaction Cost Theory

Williamson (1975) suggests that the choice of a mode of governance can be explained by three decision variables: the frequency with which a transaction is made, the underlying uncertainty and risk associated with the transaction, and the uniqueness, or specificity, of the asset being exchanged. For different set of values of these variables, managers can either rely on market governance mechanisms (e.g. competition, bidding, use of contract) or internalise the transaction by exerting hierarchical control. Alternatively, a hybrid governance mode, consisting in an alliance or a partnership with a supplier, can be used to capture benefits present in both markets and hierarchical modes of governance or to mitigate risks.

The extent to which the objectives of the decision are attained is uncertain and different levels of uncertainty (information availability, opportunistic behaviour) also affect the choice of a governance mode.

\subsubsection{Analytical Questions}

The key questions which should be addressed by comparing the case observations with theoretical predictions are:

1. How does cultural risk, cultural risk combined with industry-level effects, and more generally transaction costs, affect the role and co-ordination mode of foreign factories? 
2. Are there alternatives organisational arrangement beyond pure outsourcing, subsidiaries, and joint ventures?

3. Under which conditions are outsourcing, subsidiaries and other organisational arrangements preferred?

4. Is "making the most of a foreign factory" only applicable to subsidiaries and joint ventures?

\subsubsection{Research Methodology}

The above questions are mostly exploratory in nature and they try to document whilst explaining a diversity of practices. A multiple case study approach is therefore adequate to combine the need to describe diversity (using multiple case studies selected through a maximum variation sampling strategy; Miles and Hubberman, 1994) and to explore explanatory patterns through the use of case comparison displays.

\subsubsection{Data Set}

For the sake of confidentiality, companies are coded with alphabetical letters, from A to O. All firms are textile apparel or accessories manufacturing firms, at the exception of firm $\mathrm{O}$. Firm $\mathrm{O}$ is a supply chain management service subsidiary of a very large textile buyer. It was kept in the sample because (1) it matches the definition of an offshore factory (i.e. it imports raw material and exports production abroad) and (2) it brings a useful complementary perspective on membership in international operations network. The data about each company was collected through a variety of means such as interviews and students' term projects or dissertations. Some but not all of the factories were visited.

\subsubsection{Data Collection}

Due to the exploratory nature of the research, there was no pre-designed structured questionnaire used to collect the data. Instead, each case was archived as a case study write-up. Data which was systematically collected for each case included:

- $\quad$ size of the Moroccan factory in terms of number of employees; 
- ownership of the factory;

- management organisation, especially in terms of expatriates versus local managers;

- position and role of the factory in the GPN, if any;

- local views regarding the operations strategy of the factory, along with the local view of the operations strategy of the network coordinator;

- extent of technical activities conducted in the local factory;

- extent of training programmes and effort in local factories;

- extent of collaboration, and quality of the relationship, between the network co-ordinator and the local factories; and

- rough assessment of the local factories absorptive capacity (Cohen and Levinthal, 1990).

\section{Cases}

4.1. Factory $A$ is a large facility with a capacity of 5000 pieces a day (skirts and trousers). It was initially an independent capacity subcontractor of a UK client, which after 10 years decided to invest in a joint venture to fuel local growth. Factory $\mathrm{A}$, as a result, is held at $50 \%$ by its foreign parent, although the parent has made it clear that there will be no further equity investment. Seven expatriates work in the factory. The parent is a UK-based apparel designer and manufacturer that supplies three endcustomers. The end customers have the right to impose exclusivity of usage of factories. For example, if end customer $\mathrm{X}$ uses factory $\mathrm{A}$, it has the right of forbidding factory $\mathrm{A}$ to work for other end customers. Moreover, the end customer visits and audits the facility directly. Factory A is part of a 17 factories network, including 6 in Morocco. The factory is aware of achieving low quality performance, and as a result, is allocated simple products (e.g. skirts). More complex products are allocated to better plants (e.g. coats in Ukraine). Investment was motivated by low labour cost. Sourcing is managed centrally, and purchasing negotiations of raw material are usually handled by the end client. Raw materials are 
imported, although the policy is to encourage local sourcing (Turkish facilities in the network do so) but this is dependent on the quality of fabrics available in the local market. Factories in the network are independent. Product and process design are centralised by the parent. Local process adjustments are made and validated by headquarters. Planning and scheduling is a central function, whereas maintenance management is local. Factory A has an innovative self-quality control system which could be adopted at the network level

4.2. Factory $B$ is shoe manufacturer with 1010 employees and a theoretical capacity of 10,000 pairs of shoe per day over 18 production lines. It is owned at $100 \%$ by a German parent and is used to produce some models of shoe with a long lifecycle of 8 years. The factory is managed by 9 expatriates. Marketing and sales are handled by headquarters. Factory B operates as a bonded warehouse, and is part of global network of 10 factories. Product and process design responsibilities are centralised at headquarters level. As the central design office only deals with prototypes, adjustment are necessary, so process is tuned-up locally, although modifications have to be validated by the central design department. Investment decisions are financed locally but authorised at headquarters. Factories in the network are independent, at the exception of some factories within the same country that feed one another. Cross-factory co-ordination and shipment is centralised at headquarters. Most raw materials are imported from Italy by the headquarters. Collaboration between sites is not encouraged and most sites perceive that they are in competition. All factories are similar, at the exception of a Slovenian factory which has more autonomy and the status of a lead factory within the network.

4.3. Factory $\mathrm{C}$ is a Moroccan-held factory employing 750 employees. It works for two French clients, each representing $50 \%$ of turnover. The widespread contract clause of factory exclusivity used in Morocco is waived as factory C's divided its factory in two distinct workshops and because the end products produced in each workshop corresponds to two different market segments (sports and work 
clothes). Both segments, though, require skills in assembly as the products tend to be elaborate. The factory is operated as a bonded warehouse. Client 1 is a producer itself, and it purchases and ship materials and products designs directly to Morocco. Two permanent expatriate technicians work in the corresponding workshop. Client 2 has an agent in Morocco which handles delivery of documents and all shipment issues, and thus, factory $\mathrm{C}$ is rarely is direct contact with client 2 . The agent of client 2 , though, actively invests in suppliers development initiatives, and this has resulted in the second workshop acquiring some leading edge cutting and apparel assembly technologies. Company $\mathrm{C}$ is allowed to subcontract locally, and uses this right when there is a capacity bottleneck on certain workstations. The relationship between factory $C$ and each customer has been going on for more than 15 years. Factory $C$ is intent on developing its operational flexibility, especially in terms of volume and delivery date variability.

4.4. Factory $D$ is a 1500 -employees textile apparel industry led by a Moroccan manager and three expatriates. The factory is $100 \%$ owned by a UK parent which uses it to supply two clients. The factory is part of a global supply chain and its creation was motivated by access to low labour costs. The factory handles labour-intensive operations in a process which starts and finishes in England. Some suppliers of the parent have started relocating in Morocco to further the efficiency of factory $D$. Factory $D$ is one factory in an international manufacturing network of 16 countries, with a total of 21,000 employees, including 4,000 in Morocco.

4.5. Factory $E$ is a small, locally owned, textile firm employing 120 employees and with a production capacity of 2000 pieces/day. It has one unique customer based in France, and all communications with the customer are handled by the owner. The customer has a portfolio of 4 brand names, each of which subcontracts their production partially to the 4 production line of factory E. Product design and sourcing 
is the responsibility of the customer. All other operations management functions are local: process design (including process engineering), maintenance, and quality control.

4.6. Factory $\mathrm{F}$ was initially a Moroccan capacity subcontractor that entered into a $50 \%$ joint venture with its unique UK customer. Its employs 1500 employees and operates as bonded warehouse. As it is used as an internal supplier by the UK partner, Factory $\mathrm{F}$ does not deal with product design and marketing activities. A factory part of a large international manufacturing network, factory $F$ handles all operations relative to the production of skirts and trousers. Sourcing and product design are managed by the UK partner. Other operations management functions are handled locally, and are supported by a large team of expatriates at different hierarchical levels.

4.7. Factory $G$ is a Moroccan-held textile apparel firm with 500 employees working for 4 European customers. Exclusivity is required by each customer, and is respected by factory $\mathrm{G}$ as each customers operate in non-competing segments. Factory G operates as a bonded warehouse. Customers send in orders along with product design, material, loading and sequencing instructions, and quality targets. Each line is dedicated to one customer. Local activities are limited to co-ordination, load balancing, process and quality control, and maintenance.

4.8. Factory $\mathrm{H}$ is a Moroccan-held business, with 650 employees and a production capacity of 15000 pieces per day. Firm $\mathrm{H}$ specialises on the production of baby apparel. The company has product design capabilities and has its own showroom and product catalogue. It is an independent factory with a full range of operations management capabilities: product and process design, maintenance, quality, inventory management (MRP), etc. The company works either as a capacity subcontractor (all sourcing and product design from the customer) or as a product designer.

4.9. Factory I is a Moroccan-held textile business employing 450 employees. It has 3 production lines and it serves a variety of customers in Europe and the US. I is an independent factory with basically two 
operating mode. Some customers send their product design, all materials and supplies, and their own quality controllers. Others come with a concept design and subcontract the project management of the new product development to I. Sourcing arrangements vary. I has all the internal operations management capabilities of a fully autonomous company.

4.10. Factory $\mathrm{J}$ is a textile business with 500 full time employees, a capacity of 6000 pieces per day over 8 production lines. It is a $100 \%$ owned subsidiary of an Italian company. Although a fully-owned subsidiary, $\mathrm{K}$ has its own commercial department. $\mathrm{K}$ product range is more specialised than that of its parent, and it works as independent factory with twice the manufacturing capacity of its parent. The network design approach used by the parent is to specialise factories by products. The Moroccan affiliate is autonomous, with its local operations management capabilities are: product and process design, maintenance, quality management, sourcing. Customers usually send designs and materials, but this mode of operations is not always the rule.

4.11. Factory $\mathrm{K}$ is a Moroccan-held textile firm with 200 employees. It works for 7 different French companies on a contract basis and operates as bonded warehouse. Product design is the responsibility of the clients. The supply of material is also managed by the client. The factory is autonomous, and handles its production planning and scheduling by itself. Layout decisions and technology decisions are its responsibility. The company also manage its own maintenance programme and is allowed to subcontract. When subcontracting, permission has to be sought from the customer. Subcontracting can only be justified by a short-term capacity shortage. $\mathrm{K}$ has an internal quality department, which enforces the standards sent by each customer.

4.12. Factory $L$ is a Moroccan-held textile firm employing 113 persons and specialises in the production of sweaters. It is managed by a team of 5 managers and textile engineers. Its production capacity is 2000 sweaters per day. L works for a unique French client, itself a manufacturer of sweaters, which 
handles all sales and distribution operations. The relationship is exclusive. Factory $L$ is part of a three factories exclusive supplier network shipping production to the head factory in France. Commercial negotiations are handled by the head factory. It assigns certain orders to $L$. $L$ is then in charge of receiving customers requirements, source the materials (often, the supplier is specified by the customer), and assigns the order to production (again, the customer may impose machine requirements). The local manager was trained at the head factory. The restriction of technical activities is however specific to $L$ : the other network members have more autonomy in terms of technology management and product design.

4.13. Factory $M$ is a textile firm with 1653 employees. $M$ is $100 \%$ owned by the European branch of a large US textile multinational. It works solely as an internal supplier and operates as a bonded warehouse. Operations are restricted to sewing and knitting. Operations which are not labourintensive (e.g. cutting) are located elsewhere. The full product manufacture cycle is: North Europe (purchasing, cutting), Morocco (sewing), and then back to North Europe (finishing and packaging, distribution).

4.14. Factory $N$ is a textile apparel firm with $\quad 230$ employees, led by a French entrepreneur settled in Morocco. It was initially a joint venture between the manager and a French investor, but the investor eventually bought the manager's share and now fully owns the firm. The production capacity is 500 coats per day. $\quad \mathrm{N}$ has a commercial department and handles its own commercial negotiation with customers, all based in France. $\mathrm{N}$ is not part of a manufacturing network. The company works as a capacity supplier and has a dozen of long standing customer references. There is no product design activity, but local management has full control over technology and production decisions.

4.15. Firm $\mathrm{O}$ is a $100 \%$-owned subsidiary of a French sports clothes chain employing 100 employees in Morocco. Firm $\mathrm{O}$ is best described as a subcontracting "outpost". $\quad$ In other words, $\mathrm{O}$ is an 
organisation designed to manage the extensive relocation programme of its parent's manufacturing subcontracting from France to Morocco. The parent enters orders in an ERP system used by 0. Depending on the nature of the product, the order is routed to one of the supply chain managers employed by 0 . O employs a total of 70 supply chain managers, who place orders within a pool of preapproved capacity subcontractors in Morocco. Overall, the whole supply network has an aggregate number of 3000 textile workers. The supply chain managers are responsible for inbound and outbound logistics, monitoring and control, and the development of high quality work practices. Monitoring duties extend to the financial health of suppliers. O has one local quality inspector who verifies outbound shipments. Purchasing of raw material is managed by the parent, and materials are imported from Europe. O has its own IT department.

\section{Data Analysis and Discussion}

\subsection{Diversity of Observations and Generability}

The previous section exhibits a surprising diversity of organisational configurations and arrangements. Inevitably, a qualitative research methodology such as the one used in this paper raises questions about the representativeness of the data used. The diversity of observations is a consequence of the variation sampling strategy (Miles and Huberman, 1994) which was used. Thanks to this approach, a rather exhaustive list of organisational configurations in use in the Moroccan textile industry has been documented. The question of whether or not the sample composition is representative of the composition of the population is a different matter. The 14 cases presented in the previous section were sampled for relevance and quality out of data collected about more than 40 organisations. Originally, the research was geared toward surveying only foreign affiliates which are part of a GPN network. Such firms were difficult to find, whereas other types of arrangements were plentiful. Moreover, the sample composition was analysed critically through discussions with industry experts and manufacturing associations. For all these reasons, although it cannot be claimed that the sample is 
statistically representative of the population, it can be said that qualitatively speaking, it provides a fair estimate of organisational diversity in the Moroccan textile industry.

\subsection{Overall Observations}

Only factories $\mathrm{D}$ and $\mathrm{M}$ match the specifications of a hierarchically controlled offshore factory which is part of an integrated GPN where factories are specialised. B and J are also two foreign affiliates, but they operate independently of over firms in their networks. Similarly, only firms $\mathrm{H}$ and I match the specification of an independent capacity subcontractor corresponding the market mode of governance. All other organisational forms differ slightly from what would be expected in theory.

\subsection{Transaction cost theory}

One would expect low risk transactions (e.g. standard, non fashion-sensitive textile apparel) to be associated with the market mode of governance. When technical complexity (e.g. a hunting jacket) or variability (e.g. fashion-sensitive goods) increase, one would expect that joint ventures or ownership would be preferred means of controlling foreign operations. Table 1 shows a display of the cases from a transaction cost perspective and suggests the opposite. In the Moroccan textile industry, the hierarchical mode of governance is associated with very simple and risk-free transactions. The market mode of governance is associated with more complex or fashion-sensitive transactions. Although this could appear to contradict theory, it lends support to the thesis that the co-ordination costs of foreign affiliates are high. Therefore, it is preferable for a parent firm to reduce the technical complexity of foreign affiliates in order to reduce aggregate risk levels. As the Moroccan textile industry is infamous for its often tense relations with foreign parents, it is assumed that these costs of co-ordination are primarily linked to cultural issues. For example, in 2007, a large textile operator decided to close a Tangiers-based factory where workers had been on strike for 6 months, despite receiving some of the highest wages in the industry. The factory was 1 in a network of more than 2000 factories around the globe. Similarly, in 2002, a German family firm involved its embassy to attempt to make a formal 
complaint about the unproductive problems encountered with the workforce and with the Moroccan administration. The family firm abandoned plans to relocate its production facilities in Morocco and reopened its factory in Germany. In the case of this paper's sample, the case observations show very strict control from headquarters and very large teams of expatriates to enforce production standards for foreign affiliates.

Proposition 1: The cost of operating a foreign affiliate when taking into account cultural issues is such that foreign affiliates tend to concentrate on relatively low risk, frequent, and non-specific transactions.

\subsection{Integrated Global Production Networks}

Cross-lateral co-ordination is rare and is only observed in cases D and M. All other firms operate independently, i.e. there is no sequential dependence between factories. This suggests that the cost of co-ordination is even higher for these arrangements, and thus that not many multinationals will invest in such networks. Investing in an integrated GPN member (i.e. sequential dependence exists) indicates a desire to capitalise on specialisation. The motive for investing in a set country and specific processes is to derive benefits from the experience curves of specialist local firms. On the other hand, investing in non-integrated GPN members is more likely to be a strategy motivated by taking advantage of a comparative advantage, i.e. low cost of labour.

Proposition 2: Integrated global production networks, where sequential dependencies exist amongst factories within the network, are difficult to co-ordinate. Thus, unless technical role is dramatically simplified, or unless the foreign affiliate exhibits a genuine unique competency, most multinationals invest in non-integrated networks, i.e. less structured portfolios of factories. Economic benefits are derived from diversification effects rather than from synergistic effects. 


\begin{tabular}{|c|c|c|c|}
\hline Factory & Decision Variables & $\begin{array}{l}\text { Mode of } \\
\text { Governance }\end{array}$ & Comments \\
\hline A & $\begin{array}{l}\text { Frequent, common, and low risk } \\
\text { transactions }\end{array}$ & Hybrid & $\begin{array}{l}\text { Equity participation justified by need to } \\
\text { finance growth. } \\
\text { Factory is independent within the } \\
\text { network. }\end{array}$ \\
\hline B & $\begin{array}{l}\text { Frequent, common and stable, } \\
\text { low risk transaction }\end{array}$ & Hierarchical & $\begin{array}{l}\text { Very limited local technical role, } \\
\text { handled by expatriates. }\end{array}$ \\
\hline $\mathrm{C}$ & $\begin{array}{l}\text { Frequent, fashion-sensitive, } \\
\text { variable and medium-risk } \\
\text { transactions }\end{array}$ & Market & $\begin{array}{l}\text { Strictly speaking, this is a market-based } \\
\text { governance mechanism. The } \\
\text { relationship between seller and buyer, } \\
\text { though, is very similar to a partnership. }\end{array}$ \\
\hline $\mathrm{D}$ & $\begin{array}{l}\text { Frequent, very basic and } \\
\text { specialised transaction }\end{array}$ & Hierarchical & $\begin{array}{l}\text { Part of a genuine GPN with cross lateral } \\
\text { co-ordination. }\end{array}$ \\
\hline$E$ & $\begin{array}{l}\text { Frequent, medium risk } \\
\text { transaction }\end{array}$ & Market & $\begin{array}{l}100 \% \text { reliance by supplier on a single } \\
\text { customer }\end{array}$ \\
\hline $\mathrm{F}$ & Frequent and low risk transaction & Hybrid & $\begin{array}{l}\text { Factory is independent within the } \\
\text { network. }\end{array}$ \\
\hline $\bar{G}$ & $\begin{array}{l}\text { Frequent and medium risk } \\
\text { transactions }\end{array}$ & Market & Four different customers. \\
\hline $\mathrm{H}$ & $\begin{array}{l}\text { Frequent - low to medium risk } \\
\text { transactions }\end{array}$ & Market & Pure market configuration \\
\hline I & $\begin{array}{l}\text { Frequent - low to medium risk } \\
\text { transactions }\end{array}$ & Market & Pure market configuration \\
\hline $\mathrm{J}$ & $\begin{array}{l}\text { Frequent - from low to medium } \\
\text { risk transactions }\end{array}$ & Hierarchical & $\begin{array}{l}\text { Sells either as a capacity subcontractor } \\
\text { or as a fully autonomous designer- } \\
\text { manufacturer. }\end{array}$ \\
\hline K & Frequent - low risk transaction & Market & Capacity subcontractor. \\
\hline $\mathrm{L}$ & Frequent - medium risk & Market & $\begin{array}{l}\text { Single customer - evidence of lack of } \\
\text { trust resulting local management } \\
\text { restrictions. }\end{array}$ \\
\hline M & Frequent and low risk & Hierarchical & $\begin{array}{l}\text { Part of a genuine GPN with cross lateral } \\
\text { co-ordination. }\end{array}$ \\
\hline$N$ & Frequent and medium risk & Market & Pure market configuration \\
\hline $\mathrm{O}$ & $\begin{array}{l}\text { Frequent - from low to medium } \\
\text { risk transactions }\end{array}$ & $\begin{array}{l}\text { Transition } \\
\text { from } \\
\text { hierarchical } \\
\text { to market }\end{array}$ & Supply chain outpost \\
\hline
\end{tabular}

Table 1. Case Displays from a Transaction Cost Perspective 


\subsection{Hybrid Configurations}

In table 1, the "hybrid" terminology is used to describe joint ventures stricto sensu between a Moroccan firm and a multinational investor (cases A and F). Normally, the market mode of governance should be used to refer to a situation where the suppliers are autonomous firms, in control of their operations strategy and of their daily operations management, and that employ a marketing department for their commercial representation. Only cases $\mathrm{H}, \mathrm{N}$ and I match these specifications. This leaves factories $\mathrm{C}, \mathrm{E}$, G, K, and L that do not correspond to either market, hierarchy, or hybrid! In transaction cost theory, the hybrid mode of governance is used as a compromise between hierarchical control and market mechanisms. For example, the presence of a foreign partner in a joint venture helps to reduce the cultural risk for the investor, and the presence of the investor helps securing finance and technology for the local partner. The compromises exhibited in table 1, however, are of a different nature.

The typical capacity subcontractor arrangement can be described as follows. A Moroccan entrepreneur signs an exclusive capacity subcontracting agreement with a foreign client, typically for 5 years. Depending on the nature of the contract, the Moroccan firm may be allowed to work for other customers (operating in different segments), but it may not, and thus, the factory is equivalent to an "internal" supplier. Purchasing of materials and inbound and outbound logistics are managed by the customer. The choice of production technologies, the elaboration of production schedules, and the definition of defect rates are also defined by the customer. In other words, most capacity subcontractors operate de facto as fully owned affiliates, despite the fact no equity participation exists.

Proposition 3. The distinction between modes of governance in transaction cost theory does not accurately depict organisational arrangement in some international operations networks. In this paper, what would be classified as market suppliers operate in the same conditions than fully-owned affiliates. 


\subsection{Making the Most of Foreign Factories}

The previous finding may raise concerns of exploitation, as it appears that Moroccan entrepreneurs are financing the productive assets of multinationals with no counterpart, as they operate with the same technical and role restrictions than fully-owned subsidiaries. Conversely, if propositions 1 and 2 are accurate, and if the co-ordination cost of foreign factories is indeed high, then the practice could be explained by stating that given the high level of risk embedded in the transaction, multinationals refuse to take on that cost and push it back onto the Moroccan entrepreneurs. The second explanation is supported by table 2 . Table 2 displays a matrix comparing foreign ownership with local absorptive capacity. Absorptive capacity is the ability to make sense of new knowledge on the basis of existing knowledge (Cohen and Levinthal, 1990). Table 2 shows that foreign affiliates can be the recipient of training by the parent, but this is not necessarily the case. Independent capacity subcontractors, on the other hand, all exhibit higher levels of absorptive capacity, and all have the capacity to improve their performance, thanks to the knowledge transferred by their customers. This confirms the importance of supply chain learning (Bessant et al., 2003) and of suppliers' development initiatives (Krause, 1999) in the context of non-owned capacity subcontractors.

Proposition 4: Efforts to "make the most of foreign factories" by transferring knowledge and developing the absorptive capacity of foreign affiliates is more systematic along market supply chains than along internal supply chains.

\subsection{Classifying Observations}

Figure 3 summarises the different types of operations network topologies exhibited by the sample. In each of the cells of figure 3 , the shaded firm represents the firm for which a case study was written. 


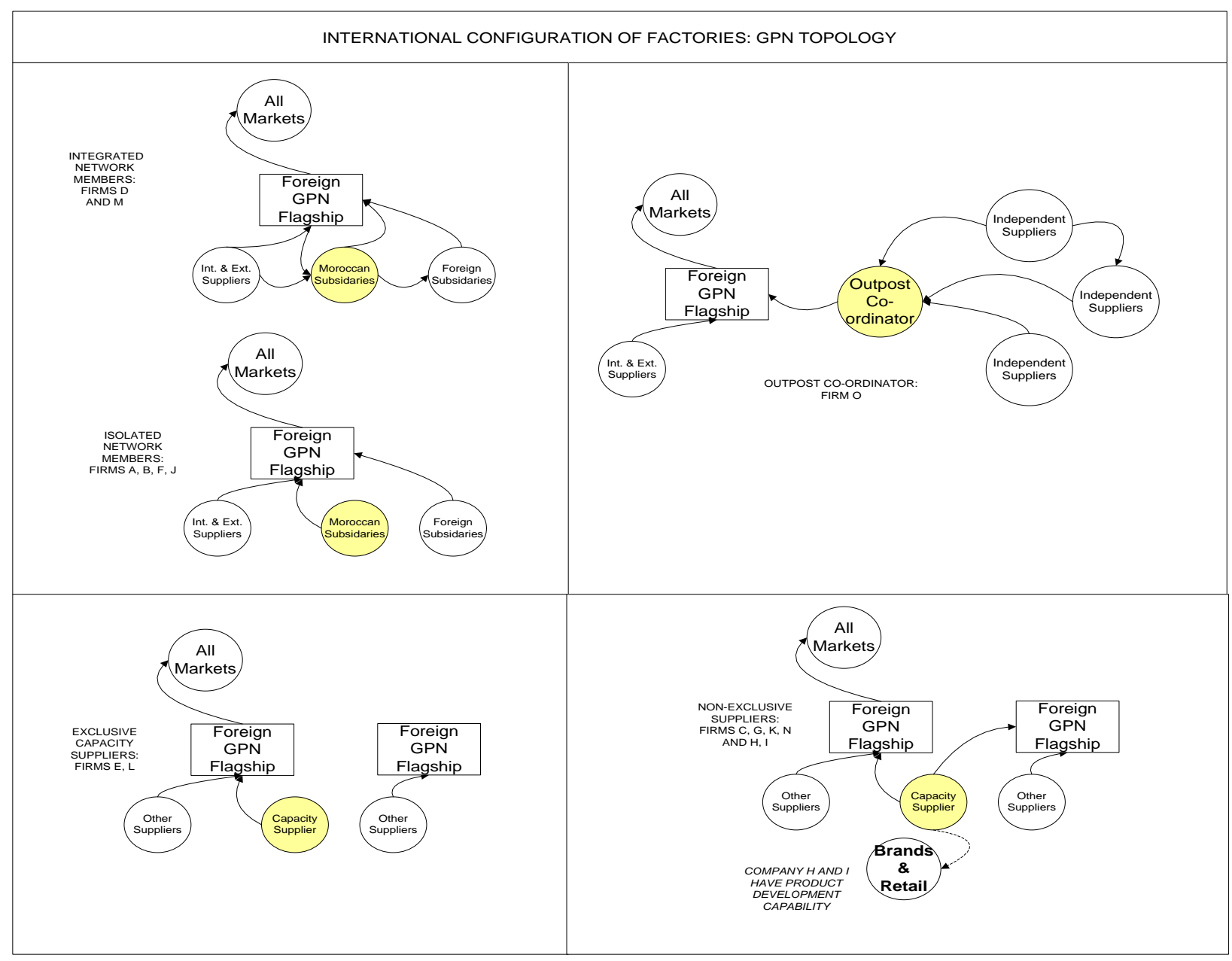

Figure 3. Different Topology for Global Production Networks

The upper left-hand cell represents the network topologies which were expected: foreign-owned subsidiaries which are part of a global manufacturing network. The integrated network member configuration (firms $D$ and $M$ ) means that Moroccan firms specialise in a specific part of a global manufacturing sequence. In contrast, isolated network members (A, B, F, and J) are responsible for a full manufacturing sequence and do not have any logistical arrangements with other networks members. Inbound and outbound logistics are almost systematically transiting through the foreign flagship, i.e. it is unusual that supplies are shipped directly from a supplier to the Moroccan subsidiary. 
The two bottom cells of figure 5 display a variety of configurations which were not expected when the research project was initiated. On the left-hand side, exclusive capacity suppliers (firms E and L) are $100 \%$ Moroccan-owned firms working for only one corporate customer and effectively controlled by this customer. Non-exclusive capacity suppliers (firms C, G, K, N, H, I) operate similarly, i.e. they sell their capacity to customers in the medium term. However, selling to different customers is allowed. In some cases, this is because the owner has negotiated a right to produce textile products in different segments. Other firms (e.g. K) are specialised in one product line and sell freely their capacity to several customers. In these cases, customers are attracted to the supplier by the quality of their work. Finally, other companies have internal product design capabilities (firms $\mathrm{H}$ and $\mathrm{I}$ ) and produce their own catalogue of product in addition to selling capacity.

\subsection{Supply Chain Outpost}

Finally, the upper right-hand cell illustrates the case of company $O$ which is a supply chain management office created to co-ordinate the suppliers working for the parent company. Firm $\mathrm{O}$ can be defined as a supply chain management outpost. It illustrates an innovative way of diffusing technologies and contributing to local economic development by strengthening the interfaces required to raise absorptive capacity whilst reducing the overall cost of co-ordination of foreign factories. In Ferdows' model (1989), outposts are firms seeking to acquire external knowledge by locating a facility of limited scale in a specialist industrial district. Research in international operations management has not provided much evidence of the existence of outposts (cf. Vereecke and Van Dierdonck, 2002). In this paper, we document the case of an outpost of a different nature: that of a knowledge supplier rather than that of a knowledge recipient. The business success of firm $\mathrm{O}$, its positive contribution to the profitability of its foreign parent, and the profitability of the firms belonging to its network suggest that more research about knowledge supplying outposts is needed to confirm the idea that they contribute to reduce the cost of co-ordinating foreign factories. 


\section{Conclusion}

The international operations management literature offers two key perspectives on the benefits of investing in international operations network. The first perspective is the portfolio approach, whereby exposure to risk is reduced as it is diversified away by controlling a vast set of manufacturing facilities. The second perspective is the multinationality approach, whereby synergistic effect can be captured to explore unique opportunities whilst reducing downside risk.

Contrarily to Kogut and Kulatilaka's (1994) hypothesis regarding the marginal importance of the cost of co-ordinating foreign operations, and consistently with Tong and Reuer's $(2007,2005)$ conclusion regarding the importance of this cost of co-ordination, this paper describes the surprising diversity through which textile multinationals cope with high transaction costs. The four propositions made in that paper are that the cost of co-ordination can be so high that equity investments in foreign factories (a) tend to target low technical risk transactions in order to reduce aggregate risk exposure, (2) tend to favour independent rather than integrated factory networks, and (3) tend to avoid investments altogether by dealing with independent subcontractors as if they were owned. Moreover, the case studies show that (4) systematic training and development of the foreign factories is observed in the case of market-based supply chains and not in the case of internal supply chains.

Tong and Reuer (2007) also highlight that the cost of co-ordination increases with the cultural distance between the investor and the foreign affiliate, and show that the performance benefits of multinationality can be offset by the rise in co-ordination costs. One of the case observations illustrates the practice of a supply chain management outpost, i.e. of a small structure with the purpose of interfacing cultures, systems, and initiatives between the multinational and its foreign affiliates in a country. The economics of supply chain management outposts are an interesting alternative hybrid solution in the terminology of transaction cost theory. An exciting programme for future research is to 
determine if investments in supply chain outposts, on the aggregate, would be preferable to investments in either foreign assets or relationship with contractors.

\section{References}

Bessant, J., Kaplinsky, R., and Lamming, R. (2003) 'Putting supply chain learning into practice', International Journal of Operations and Production Management, Vol. 23, No. 2, pp. 167-181.

Buckley P. and Casson, M. (1998) 'Models of the multinational enterprise', Journal of International Business Studies, Vol. 29, No. 1, pp. 21-44.

Cohen, W. M. and Levinthal, D. (1990) 'Absorptive Capacity: A new perspective on Learning and Innovation', Administrative Science Quarterly, Vol. 35, No. 1, pp. 128-143.

Ellram, L.M., Tate W.L., and Billington C. (2008) 'Offshore outsourcing of professional services: a transaction cost economics perspective', Journal of Operations Management, Vol. 26, No. 2, pp. 148163.

Ernst, D. and Kim, L. (2002) 'Global production networks, knowledge diffusion, and local capability formation', Research Policy, Vol. 31, No. 8/9, pp. 1417-1429.

Ferdows, K. (1989) Managing International Manufacturing, Elsevier Science Publishers, Amsterdam.

Ferdows, K. (1997a) 'Made in the world: the global spread of production', Production and Operations Management, Vol. 6, No. 2, pp. 102-119.

Ferdows, K. (1997b) 'Making the most of foreign factories', Harvard Business Review, MarchApril, pp. 73-88.

Julien, P., Jacob, R., and Raymond L. (1997) 'New network technologies for SMEs: Toward a metaorganisational learning system', Proceedings of the First International Conference for Stimulating Manufacturing Excellence in Small \& Medium Enterprises, Sheffield, UK, April 20-22, pp. 317-327.

Khatawala, Y., Zhang R., and Shao J. (2005) 'Global outsourcing and its impacts on organisations: problems and issues', International Journal of Services and Operations Management, Vol. 1, No. 2, pp. 185-202.

Khurana, A. and Talbot, B. (1998) 'The internationalization process model through the lens of the global color picture tube industry', Journal of Operations Management, Vol. 16, No. 2/3, pp. 215240.

Kogut, B. (1984) 'Normative observations on the international value-added chain and strategic groups', Journal of International Business Studies, Vol. 15, No. 2, pp. 151-167.

Krause, D. (1999) 'The antecedents of buying firms' efforts to improve suppliers', Journal of Operations Management, Vol. 17, No. 2, pp. 205-224. 
Li, J. and Rugman A.M. (2007) 'Real options and the theory of foreign direct investment', International Business Review, Vol. 16, No. 6, pp. 687-712.

McGrath, M. and Bequilard, R. (1989) 'International manufacturing strategies and infrastructural considerations in the electronics industry', in Ferdows, K., Ed., Managing International Manufacturing, Elsevier Science Publishers, Amsterdam.

Meijboom, B. and Vos, B. (1997) 'International manufacturing and location decisions: balancing configuration and co-ordination aspects', International Journal of Operations \& Production Management, Vol. 17, No. 8, pp. 790-805.

Meyer, A., Tsui, A. and Hinings, C. (1993) 'Configurational approaches to organizational analysis', Academy of Management Journal, Vol. 36, No. 6, pp. 1175-1195.

Miles, M.B. and Huberman, A.M. (1994) Qualitative Data Analysis, Sage Publications, Newbury Park, CA.

Reuer, J.J. and Tong, T.W. (2005) 'Real Options in International Joint Ventures', Journal of Management, Vol. 31, No. 3, pp 403-423.

Reuer, J. and Leiblein, M.J. (2000) 'Downside risk implications of multinationality and international joint ventures', Academy of Management Journal, Vol. 43, No. 2, pp. 203-214.

Shi, Y. and Gregory, M. (1998) 'International manufacturing networks - To develop global competitive capabilities', Journal of Operations Management, Vol. 16, No. 2/3, pp. 195-215.

Stringfellow, A., Teagarden, M.B. and Nie, W. (2008) 'Invisible costs in offshoring services work', Journal of Operations Management, Vol. 26, No. 2, pp. 164-179.

Tong, T.W., Allessandri, W. Reuer, J.J. and Chintakananda, A. (2008a) 'How much does country matter? An analysis of firm' growth options', Journal of International Business Studies, Vol. 39, No. 3, pp. 387-405.

Tong. T.W., Reuer, J.J. and Peng, M.W. (2008b) 'International joint ventures and the value of growth options', Academy of Management Journal, Vol. 51, No. 5, pp. 1014-1029.

Tong, T.W. and Reuer, J.J. (2007) 'Real options in multinational corporations: organizational challenges and risk implications', Journal of International Business Studies, Vol. 38, No. 2, pp. 215-230.

Vereecke, A. and Van Dierdonck, R. (2002) 'The strategic role of the plant: testing Ferdows's model', International Journal of Operations and Production Management, Vol. 22, No. 5, pp. 492-514.

Williamson, O., (1975), Markets and Hierarchies, Free Press, New York.

Williamson, O., (1985), The economic institution of capitalism: firms, markets and relational contracting, Free Press: New York. 


\begin{tabular}{|c|c|c|c|c|c|c|}
\hline $\begin{array}{l}\text { Foreign Ownership } \\
\text { (Firms) }\end{array}$ & $\begin{array}{l}\text { Intensity of } \\
\text { effort to } \\
\text { acquire } \\
\text { knowledge }\end{array}$ & $\begin{array}{c}\text { Quality of } \\
\text { communication } \\
\text { flows/ } \\
\text { communication } \\
\text { architecture }\end{array}$ & $\begin{array}{l}\text { Interface } \\
\text { between } \\
\text { buyer and } \\
\text { seller }\end{array}$ & $\begin{array}{c}\text { Knowledge } \\
\text { diversity } \\
\text { Where is diversity } \\
\text { coming from? }\end{array}$ & $\begin{array}{l}\text { Trade-off } \\
\text { between } \\
\text { internal and } \\
\text { external } \\
\text { sources of } \\
\text { knowledge }\end{array}$ & $\begin{array}{l}\text { Management of } \\
\text { absorptive } \\
\text { capacity: proactive, } \\
\text { potential for } \\
\text { improvement, or } \\
\text { inability to learn } \\
\text { (lockout) }\end{array}$ \\
\hline \multicolumn{7}{|l|}{ Domestic } \\
\hline $\mathrm{D}(0 \%)$ & High & Good/Open & Good & Good (portfolio) & Good & Proactive \\
\hline $\mathrm{K}(0 \%)$ & High & Poor/Central & Average & Good (portfolio) & Inward & Potential \\
\hline G (0\%) & High & Good/Open & Good & Good (portfolio) & Good & Proactive \\
\hline $\mathrm{H}(0 \%)$ & High & Good/Open & Excellent & Good (portfolio) & Good & Proactive \\
\hline I (0\%) & High & Good/Open & Excellent & Good (portfolio) & Good & Proactive \\
\hline$E(0 \%)$ & High & Good/Open & Average & Good (portfolio) & Inward & Potential \\
\hline $\mathrm{L}(0 \%)$ & High & Good/Open & Poor & Low & Good & Potential \\
\hline \multicolumn{7}{|l|}{ Joint Venture } \\
\hline $\mathrm{A}(50 \%)$ & Low & Avg/Central. & Poor & Good (network) & Inward & Potential \\
\hline$F(50 \%)$ & Very High & Good/Central & Poor & Good (network) & Good & Proactive \\
\hline \multicolumn{7}{|l|}{ Foreign Owned } \\
\hline $\mathrm{B}(100 \%)$ & Low & Poor/Central & Poor & Good (network) & Inward & Lockout \\
\hline $\mathrm{D}(100 \%)$ & High & Good/Open & Average & Good (network) & Good & Proactive \\
\hline$J(100 \%)$ & High & Good/Open & Good & Good (network) & Good & Proactive \\
\hline $\mathrm{M}(100 \%)$ & Low & Avg/Central & Poor & Low & Inward & Lockout \\
\hline $\mathrm{N}(100 \%)$ & Low & Poor/Central & Good & Low & Inward & Lockout \\
\hline
\end{tabular}

\footnotetext{
Table 2 . Across Ownership Case Display of Absorptive Capacity
} 